\title{
Web-foorum aidon yhteistyön välineeksi
}

\author{
Riitta Kuusinen
}

\author{
Sosiaalinen toimintaympäristö on osallisena yksilön kog- \\ nitiivisessa tiedonkäsittelyssä. Ihminen ei opi vain asiatie- \\ toja ympäristönsä mukaisten käsitteiden varassa. Sen \\ rinnalla ihminen oppii sosiaalisissa toimintaympäristöissä \\ vaadittuja selviytymismalleja, toimintamalleja. Tämä toi- \\ mintaoppiminen tapahtuu tiedostamatta, salakavalasti.
}

$\mathrm{T}_{\mathrm{t}}$ ieto elää ihmisessä. Se oli lähtöoivallus aloittaessamme tietoliikennetekniikan käytön pilottihanketta vuonna 1995. Eri puolilla Suomea oli toisistaan erillisiä ammatillisen koulutuksen kehittämishankkeita. Euroopan unionin ammatillisen koulutuksen kehittämiskeskus CEDEFOP ja Suomen opetushallitus etsivät mahdollisuuksia näiden hankkeiden voimavarojen yhdistämiseksi ja tarjosivat projektillemme tuota ideointitehtävää. Alkoi tutkimus- ja kehittämisprojekti, joka on toteutettu Tampereen yliopiston Työelämän tutkimuskeskuksessa. Oli innostavaa miettiä, miten hankkeet voisivat saada toisistaan tietoa tietoliikenneverkon välityksellä ja sitä kautta päästä vuorovaikutukseen keskenään - parhaassa tapauksessa tekemään tietointensiivistä yhteistyötä ja tuottamaan yhteistä tietämystä.

Uuden teknologian avulla haluttiin luoda tutkimushankkeille yhteinen foorum, Internetin kautta käytettävä www-tietokanta. Sitä suunniteltiin ensisijaisesti ihmisten välisen tiedonkäsittelyn apuvälineeksi. Kun apuvälinettä, webfoorumia, halutaan käyttää vuorovaikutuksellisesti, omaehtoisesti ja vapaamuotoisesti, siirrytään lähemmäksi yksittäisten ihmisten tietämysja toimintatasoa. Tiedontuottamisyhteistyötä tekevien ihmisten on esiteltävä omaa tietämystään, tutustuttava toisten tietämykseen, arvioitava esiin tuotua tietämystä yhteisen tavoitteen kannalta, etsittävä yhteistä ymmärrystä, luotava yhteistä käsitteistöä ja omaksuttava yhteistä tietämystä. Web-avusteinenkin tiedontuottamisyhteistyö on siten ihmisissä elävän tiedon käsittelyä, samasta aiheesta kiinnostuneiden ryhmä- tai yhteisöjäsenten sosiaalista tiedonkäsittelyä, jossa ns. yhteistyökyky joutuu koetukselle.

Näen tiedontuottamisyhteistyön ryhmäilmiönä. Tutkimuksessa on sen peruselementtejä hahmotettu teoreettisella tasolla eli kokeilutoiminnan tarjoamista käytännön vihjeistä on kirjallisuuden ja omien johtopäätösten avulla etsitty yhteistyötä hahmottavaa teoriaa. Tavoitteena on ollut koota käyttäytymistieteellistä teoriaperustaa uudenlaiselle työskentelytavalle, tietämyksen web-avusteiselle ryhmäprosessoinnille. Tiedontuottamisyhteistyö näyttää tämän tutkimuksen tulosten mukaan rakentuvan kolmesta perustavasta tapahtumaprosessista:

- yksilöiden kognitiivisesta tiedonkäsittelystä

- yhteisen toiminnan organisoinnista ja

- ryhmäkäytännöistä, joissa tapaamiset ja tasaarvoinen keskustelu ovat keskeisiä toteutus keinoja.

Nämä yhteistyöprosessin keskeiset elementit tulivat esiin tutkimuksen kokeilujaksossa, joka toteutettiin vuosina 1996 ja 1997. Kokeiluyhteisönä oli Euroopan Unionin Sosiaalirahaston ohjelmaa 4.1 Suomessa toteuttavat hankkeet. Niitä yhdistävänä aiheena oli työelämän ja koulutuksen muutosten ennakoiminen. Käytännössä hank- 
keiden rahoitus oli kanavoitu työministeriön, opetusministeriön sekä sosiaali- ja terveysministeriön kautta ja samalla ministeriöt valvoivat näiden ESR-rahoituksella toteutuvien hankkeiden työskentelyä. Ennakointihankkeita oli kokeilumme alkuvaiheessa yli 60 ja loppuvaiheessa yli 80 . Eri puolille Suomea hajasijoittuneet hankkeet muodostivat siis sen yhteisön, jolle meidän tutkimusprojektimme tarjosi uudenlaista viestintämahdollisuutta, heitä varten perustettua webfoorumia.

Nimenomaan tiedontuottamisyhteistyö osoittautui käytännössä erittäin vaikeaksi - jopa niin vaikeaksi, että se ei edes käynnistynyt. Juuri sen ongelmallisuus herätti halun analysoida tiedontuottamisyhteistyötä teoreettisella tasolla kasvatuspsykologiasta selityksiä etsimällä.

Tutkimusaineisto on siis saatu kokeilutoiminnan kautta. Siinä toteutui toimintatutkimuksen periaatteet sikäli, että tutkija oli toimintayhteisössä aktiivisesti mukana, mutta kunnioitti yhteisön tavoitteita ja asiasisältöjen käsittelyä. Kokeilu viittaa tässä tutkimuksessa uudenlaisen viestintämahdollisuuden käyttöönottoon ja se ilmaisee kokeiluyhteisöllekin ennestään tuntematonta viestintätoimintaa. Minulle tutkijana lankesi aktiivinen rooli viestintävälineen ominaisuuksien esittelyssä, käyttöönoton ohjaamisessa ja käyttäjien oppimisen tukemisessa.

$\mathrm{K}^{\mathrm{o}}$ okeilutoiminnassa suureksi ongelmaksi osoitautui yksilöiden passiivisuus. Jokaisella hanke-edustajalla piti olla omanlaistaan ennakointitietoa. Minä olin antanut opastusta ja esimerkkejä viestintävälineen käytöstä, asiasta muistutettiin yhteisön sisäisessä sähköpostiviestinnässä vähän väliä, ja teknistä apua oli tarjolla. Yhteisöjäsenet osoittivat passiivisuudestaan huolimatta positiivisia asenteita, jotka tulivat esiin tekemässäni kyselyssä. Pinnallisesti tulkiten passiivisuusongelman saattoi leimata ihmisten yhteistyökyvyttömyydeksi. Syvällisten syiden etsintä johti kognitiivisen tiedonkäsittelyn ydintapahtumien selvittelyyn.

Sosiaalisessa tiedonkäsittelyssä avautui uusi tärkeä perspektiivi: oppiminen kognitiivisen tiedonkäsittelyn tuloksena sitoo ihmiset menneisyyteensä. Ihminen ei opi vain asiatietoja ympäristönsä mukaisten käsitteiden varassa. Sen rin- nalla ihminen oppii sosiaalisissa toimintaympäristöissä vaadittuja selviytymismalleja, toimintamalleja. Tämä toimintaoppiminen on siitä salakavala, että se tapahtuu tiedostamatta eli ihminen ei itse tietoisesti ohjaa oppimistaan vaan sen hoitelevat aivot itsenäisesti sosiaalisen toimintaympäristön ohjauksessa. Siten sosiaalinen toimintaympäristö on osallisena yksilön kognitiivisessa tiedonkäsittelyssä.

Opitut toimintamallit automatisoituvat eli ne laukeavat sopivissa tilanteissa aktiivisiksi. Visuaalinen havainnointi on sekä oppimisvaiheessa että käyttövaiheessa tärkeä informaatioväylä. Aivojen toimintaa ohjaava automatiikka vapauttaa tietoisen työmuistin rajoitetun kapasiteetin asiasisältöjen käsittelyyn. Huomionarvoista on, että automatisoitunut toimintamalli osallistuu aktiivisesti jo ympäristössä tarjolla olevan informaation havainnointiin ja valikointiin, kiinnittää huomion opittujen selviytymismallien kannalta merkitykselliseen informaatioon ja tekee ihmisen kognitiivisesti sokeaksi toisenlaisten toimintamallien mahdollisuuksille. Tämä kognitiivinen ilmiö tunnetaan työelämässä muutosvastarintana.

Sosiaalisen tiedonkäsittelyn perusmalli opitaan koulussa. Siellä toimintastrategiana on rinnakkainen tiedonkäsittely. Toimintamalli on yksilökeskeinen, jopa itsekeskeinen, koska jokaisen on annettava vain omasta tiedonkäsittelystään näyttöjä yhteisön johtajalle eli opettajalle. Samalla opitaan auktoriteettijohtoinen sosiaalinen toimintamalli ja siihen liittyvä suorituspainotteinen asenne omaan tiedonkäsittelyyn ja oppimiseen. Vuosia opeteltu toimintamalli on hyvin automatisoitunut ja siitä on kiteytynyt ajattelumalli, jota on myös vaikea tiedostaa ja muuttaa. Tätä kautta meillä on tilanteeseen liittyviä arvoja, asenteita ja tunteita, joista arvostelun pelko on yhteistyön kannalta yksi haitallisimmista. Toiminta- ja ajattelumalleja sovelletaan tiedostamatta työelämän sosiaalisiin tiedonkäsittelytilanteisiin - kuten tulkintani mukaan tapahtui myös tiedontuottamisyhteistyön kokeilussa.

$\mathrm{T}$ iedontuottamisyhteistyössä tarvittaisiin ryhmäkeskeistä toimintamallia, mutta sellaisen oppiminen on mahdollista vain yhteisen tiedonkäsittelyn mukaisessa toiminnassa. Se taas ei synny ilman ryhmäkeskeistä toimintastrategiaa. Kou- 
lussa opitun perusmallin takia ryhmäkeskeisen toimintamallin opettelu vasta työelämässä vaatii lisäksi itsekeskeisten toimintamallien poisoppimista. Nämä oppimiset ovat erittäin hitaita ja kognitiivisesti rasittavia. Ihminen alistuu uusien toimintamallien oppimiseen vain olosuhteiden pakosta. Lisäksi toimintaoppiminen vaatii toistuvaa omakohtaista tekemistä. Aitoon ryhmäkeskeiseen tiedonkäsittelyyn harvoilla työpaikoillakaan on vielä mahdollisuuksia.

Yhteistyöprosessin jäsenet edustavat yksilöille tilapäistä sosiaalista toimintaympäristöä, joka konkretisoituu tapaamisissa ja joka on välttämätön osa kognitiivista ja yhteistä tiedonkäsittelyä. Yhteistyön toimintastrategiassa on mahdollista tietoisesti pyrkiä ryhmäkeskeiseen toimintaan niin, että ryhmä positiivisessa hengessä patistaa yksilöitä yhteiseen tiedonkäsittelyyn. Ryhmä siis toisaalta toimintastrategiallaan luo olosuhteiden pakkoa ja samalla tarjoaa yhteisötukea ryhmäkeskeisten tiedonkäsittelymallien opettelulle.

Yhteistyöprosessin organisatorisia puitteita voi tiedostaa kuvittelemalla sitä varten perustettavaksi virtuaalisen yhteistyöorganisaation eli vytorganisaation. Sen toimintastrategian suunnittelu on keskeisessä asemassa. Vastuuhenkilön on hyvä olla tietoinen toimintastrategian periaatteista ja tuoda sen toteutumisen seurantaa ryhmäkäsittelyyn. Vastuuhenkilön on hyvä olla myös tietoinen siitä, että jokaisella, myös hänellä itsellään, on taipumus sortua yksilökeskeiseen toteutukseen. Osallistuva johtaminen ja tasa-arvoinen keskustelu ovat tavoiteltavia toimintamuotoja myös vyt-organisaatiossa, kuten missä tahansa organisaatiossa.

Alkaneen yhteistyöprosessin onnistumiselle ratkaisevin ryhmäkeskeinen taito on yhteisen toiminnan yhteinen arviointi ja säätely. Sen avulla ryhmä ylläpitää ja huoltaa yhteistyöprosessia. Käsite yhteistyökyky viittaa mielestäni ihmisen yksilökeskeiseen osaamiseen. Ryhmäilmiössä käsite kyseenalaistuu ja sen tilalle sopivammalta tuntuu käsite yhteistyöhalu. Jos jokaisella yhteistyöjäsenellä on yhteistyöhalua, yhteistyöprosessin ylläpitämiseen tarvittavien ryhmäkeskeisten toimintakäytäntöjen tuottaminen mahdollistuu puutteellisista taidoista huolimatta, kuitenkin sillä edellytyksellä, että organisatoriset puitteet tarjoavat siihen konkreettisia mahdollisuuksia ja ryhmä pystyy säätelemään toimintaansa.

Tiedontuottamisyhteistyössä käsiteltävänä aineistona on yksilöllinen tietämys. Sitä voi kuvata symbolisella kuviolla.

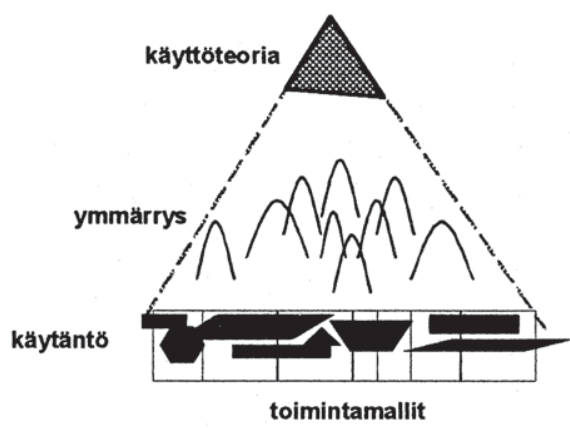

Kuvio 1: Yksilöllinen tietämys

Runkona on käsitehierarkiaa muistuttava pyramidi. Sen leveään alaosaan sijoittuvat ne käytännön ilmiöt, joissa yksilö on saanut kokemuksia ja oppinut erilaisia toimintamalleja. Niiden perusteella hän luo oman ymmärryksensä kautta itselleen käyttöteoriaa, joka on kuvion kärjessä. Tietämyksen kolmea tasoa hän täydentää ja laajentaa koko elämänsä ajan ja hän tekee sitä myös muilta kuulemansa tiedon perusteella. Hän tekee sen kuitenkin aina jo olemassa olevan tietämyksensä mukaisesti: sen avulla hän valikoi, tulkitsee ja muokkaa saamaansa informaatiota. Kyse on konstruktivistisesta oppimisesta.

Tämä symbolinen tietämyskuvio helpottaa myös muiden tiedonkäsittelyyn liittyvien ilmiöiden ymmärtämistä.

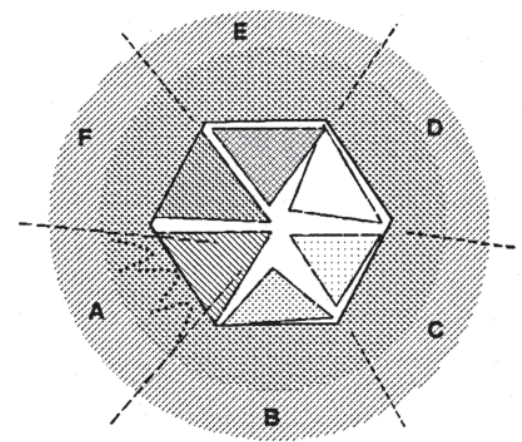

Kuvio 2. Erilaiset toimintaympäristöt yksilön kehityksessä

Ihmisen tiedonkäsittelyyn perustuva yksilöllinen oppiminen (kuvio 2) koostuu hänen erilaisissa toimintaympäristöissä saamistaan käytännön ko- 
kemuksista ja kussakin ympäristössä omaksumistaan selviytymismalleista. Sektori A voi edustaa kotia, sektori B kaveripiiriä, C koulua, D harrastusympäristöä jne. Näistä saadut opit ja merkityksellisiksi koetut tiedot mukautuvat synnynnäisiin luontumuksiin ja tuloksena muodostuu persoonallinen kokonaisuus.

Eri ihmisten vaikeus ymmärtää toistensa puhetta (kuvio 3) perustuu myös yksilölliseen tietämykseen.

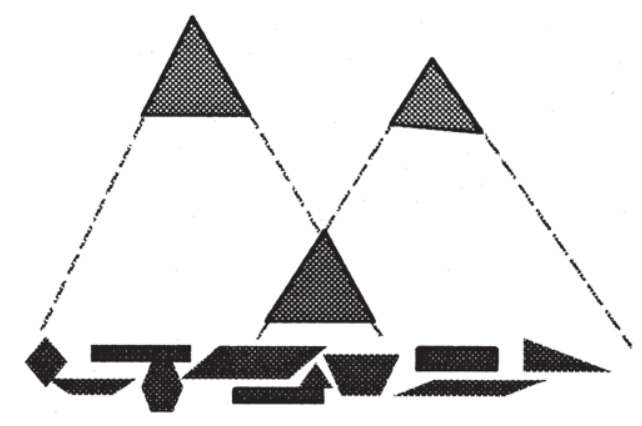

Kuvio 3. Käsitehierarkioiden kosketuspinnat

Mikäli esimerkiksi web-foorumilla esitellään omaa tietämystä pelkästään teoreettisella kärkitasolla, toisen on vaikea saada siitä kosketuspintaa omaan tietämykseensä. Näyttää siltä, että juuri käsitehierarkioiden ylätasolla yksilöiden väliset erot ovat suurimmat, joten yhteisen kielen löytyminen sillä tasolla on vaikeaa. Käytäntöön liittyvät kuvaukset taas tuovat mahdollisuuden yhteiselle kosketuspinnalle erilaisista käsitteistä huolimatta ja siltä pohjalta on helpompi aloittaa yhteisen ymmärryksen etsintä. Siksi minäkin käytän työssäni paljon käytännön esimerkkejä.

Ryhmän yhteinen tietämys (kuvio 4) koostuu teoreettisesti tarkastellen erilaisten yksilöiden tietämyksestä.

Ryhmä ei omaksu kenenkään tietoa sellaisenaan, vaan sekin valikoi, tulkitsee ja muokkaa yksilöiden esittelemää tietämystä. Siten ryhmässä syntynyt tietämys ei ole suoraan yksilöiden esittämien osien summa. Ryhmän tietämyksellä on jäsentensä kautta monipuolinen kosketus erilaisiin käytännön tapahtumiin. Siksi tietämyksen ryhmäkäsittely avartaa jokaista jäsentä, mikäli yhteinen tiedonkäsittely ryhmässä toteutuu aidosti. Ryhmän yhteinenkin tietämys elää kuitenkin ihmisissä: se on opittu ryhmäkeskuste-

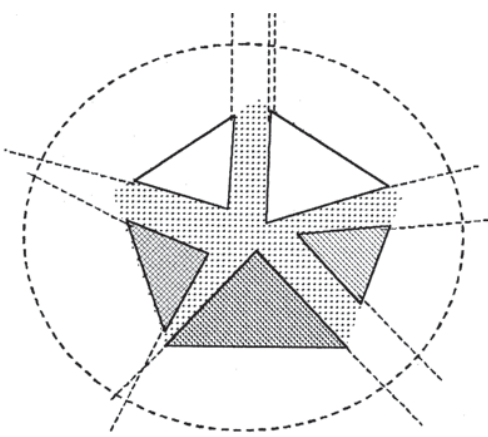

Kuvio 4. Yhteisen tietämyksen tuottaminen ryhmässä

lussa ja sosiaalisessa ympäristössä ja muokattu yksilöiden tietämyksessä. Näin muodostuu organisaatioissakin yhteinen tietämys, vaikkakin vuorovaikutus hajasijoittuu aika-akselille erilaisiin tapahtumiin. Käsite oppiva organisaatio on tätä kautta selitettävissä ihmisten tiedonkäsittelyyn perustuvaksi ilmiöksi.

Tieteellisen tiedon voi nähdä tutkijoiden esittämien tietämysten asteittaisena ja verkostomaisena tuottamisena. Siinä tieteelliset julkaisut tuovat aiheesta vähitellen kokonaisuuksiksi hahmottuvaa tietoa ja varsinkin humanististen tieteiden tietokokonaisuudet tarkentuvat eri tutkijoiden verkostomaisena tuotoksena pitkälle aikajanalle sijoittuen. Kyse ei kuitenkaan ole tiedontuottamisyhteistyöstä, joka edellyttää jonkinasteista samanaikaisuutta. Mikäli ihmisten tietämys nähdään tässä esitetyn kaltaisena, on humanistinen tieto aina suhteellista, eri ihmisten erilaisiin elinympäristöihin suhteuttamaa.

Väitöskirja esittelee minun tietämystäni tiedontuottamisyhteistyöstä. Siksi olen päätynyt kuvailemaan tietämystäni oppimisprosessin muodossa. Samalla raportti kuvailee tutkimusprosessia, jossa kokemukseni edustavat johdantoa tutkimusaiheen viriämiselle, empiiriset jaksot viitoittavat tutkijan tulkintojen kautta teoreettisiin johtopäätöksiin. Sekä oppimisprosessin että tutkimusprosessin avulla olen löytänyt käyttäytymistieteellisen teoriaperustan tietämyksen webavusteiselle ryhmäprosessoinnille, mikä oli tutkimuksen tavoitteena.

Riitta Kuusinen väitteli 24.2.2001. Tutkimus on ilmestynyt nimellä “Ongelmana yhteistyökyvyttömyys? Teoreettisen ymmärryksen etsintää web-avusteiselle tiedontuottamisyhteistyölle”. Helsingin yliopisto. Kasvatuspsykologian tutkimusyksikkö. Tutkimuksia2/2001. Yhteystiedot: ttriku@uta.fi 